\title{
Towards a Theory of the Criminal Justice System
}

\author{
Af Linda Gröning ${ }^{1}$
}

\begin{abstract}
The idea of a (national) criminal justice system as the framework for the exercise of penal power is firmly anchored in the Western discourse. At the same time, the science of criminal law does not offer any thorough normative theory of the criminal justice system as a (coherent) whole. In opposition to concepts like crime, responsibility or punishment, the concept of a criminal justice system is seldom dealt with, and its normative underpinnings are seldom discussed. This article argues that a normative theory of the criminal justice system fulfils several important functions in the development of the criminal law, not least with regard to the current restructuring of the national criminal justice system. From this point of departure, the article provides an account of the building blocks and methodological challenges of such a theory.
\end{abstract}

\section{Introductory Remarks}

This article provides some reflections about a theory of the criminal justice system. Particularly, it provides an account of the building blocks and methodological challenges of such theory. ${ }^{2}$ The criminal justice system is approached from a legal point of view. More specifically, the criminal justice system is approached as a sub-system to the overall legal order of a given political society. ${ }^{3}$ It is understood as a specific legal system, demarked mainly through its function to exercise penal power, i.e., the power to deliver and implement different kinds of authoritative decisions concerning crimes and their punishment (such as through criminalisation, sentencing or the administration of punishment). From this starting point, the criminal justice system is taken to include all those (legal) elements that formally serve this function, such as norms concerning the punishable offences and institutions that officially respond to the violation of these norms.

The theory aimed at consists primarily of a rational re-construction of the (constituting elements of the) criminal justice system as a concept or idea, and not (primarily) of a description of existing systems as empirical phenomena. Ultimately, the aspiration is to elaborate a normative framework for the system, i.e., an overall principled structure consisting of the general principles that steers (or should steer) the different elements of the system, and their interrelations, as a 
functioning whole. The article adumbrates a constitutional perspective to the criminal law. It argues that different specific principles of the system, such as principles of criminalisation or sentencing principles, ultimately must be understood as interrelated through the more basic (constitutional) principles of the system. That kind of normative theory could be used to understand or evaluate existing structures of penal power. Another thing is, and this is an important point, that also such theory must integrate empirical knowledge about existing criminal justice systems.

Criminal law theory offers discussions about different central elements of the criminal justice system, most evidently about the norms of the criminal law and criminal procedure, and about the concepts of crime and punishment. This article builds upon these discussions. However, it insists upon the necessity of an overall coherent framework for the criminal justice system, linking together (theories about) its different institutional and normative aspects. Such theoretical approach, focusing on the criminal justice system as a whole, is to a large degree lacking in the contemporary normative discourse. ${ }^{4}$ It is also to an increasing degree needed in order to steer the ongoing development of the criminal law, particularly with regard to the reconfiguration of the criminal justice system that this development carries with it. ${ }^{5}$

\section{Seeking Theory}

Before proceeding into the content of a theory about the criminal justice system, some further remarks should be made about the need of such theory. I will first briefly address the current absence of theory, and then go on to say something about why we should seek to develop one, i.e. to address the functions of a theory.

The term "criminal justice system" is a term that we are all familiar with. This term - or corresponding notions in different languages - is used in almost every European standard book on criminal law or criminal procedure. In the Western discourse, there also seems to be some kind conventional or paradigmatic understanding of a criminal justice system. This understanding refers to the institutionalised structure for the exercise of penal power that has been developed within the democratic Rechtsstaat, as the national criminal justice system. ${ }^{6}$ This structure is typically understood to include both a system of norms and an institutional organisation (of all those institutions that officially respond to the commission of offences, such as the police, prosecutors, judges and prison services). ${ }^{7}$

But what do we more concretely mean by saying that something is, or should qualify as, a criminal justice system? Could we agree on a definition in terms of necessary or sufficient criteria? Could we, for instance, agree on institutions that 
must always be present? This question links further to more concrete questions, for instance regarding the ongoing development of EU criminal law: Is it necessary to establish a common European defence agency if we establish a European public prosecutor and, if so, why? ${ }^{8}$

The contemporary Nordic discourse does not offer any comprehensive theory of a criminal justice system that goes beyond the conventional model. Criminal law doctrine is conventionally centred on problems found within the criminal justice system (problems in criminal law, problems in criminal procedure, problems related to the administration of punishment and so on). The concept of a criminal justice system is - in opposition to concepts like crime, responsibility or punishment - seldom dealt with and its normative underpinnings are seldom discussed. ${ }^{9}$

The reasons for the relative absence of a theory are certainly manifold. It is probably not without impact that the existence and privileged status of the national criminal justice system for a long time has been taken for granted as an overall acceptable structure for penal power. Another possible reason, at least from a Nordic perspective, is that a theory about the criminal justice system requires a highly interdisciplinary approach that in some aspects challenges the conventional normative approach within criminal law science. The criminal justice system is a complex entity in the intersection between law and society which refers to a multitude of competing legal, sociological and political perspectives. ${ }^{10}$ As a legal entity it also transcends the sphere of "pure" criminal law and relates to many other branches of law, such as administrative law that regulates the administration of punishment. This complex character of the criminal justice system might in the end raise some doubt about the possibilities of a theory about it.

The view of this article is, however, that there is an increasing need of a new theory of the criminal justice system, and that such theory should be sought constructed. After all, a theory of the criminal justice system could serve several important functions. The most obvious functions could be outlined as follows.

1. The "Framework" Function: On a fundamental level, a theory of the criminal justice system fulfils a central role in a more complete understanding of crime, punishment and its proper administration. It provides an account of the principled framework of the system and thereby communicates ideas of how different functions fit together. Several aspects of the criminal law are in this regard best understood and studied as parts of the structure of the criminal justice system. It is, to draw an analogy, difficult to fully understand the brain or the heart and their functions without relating it to the nature of the body itself. In order to fully understand, for instance, the principles that steer the criminal process, and their proper 


\section{Linda Gröning}

relation, it seems needed to understand the function and meaning of the process in relation to the more basic meaning of the system. More generally, without reference to some kind of principled framework, the different elements of the system cannot be perceived as (meaningful) parts of a functional whole, but the system inescapably dissolve into a plurality of uncoordinated norms, actions and actors.

2. The Pedagogic Function: A theory of the criminal justice system can as a principled framework also serve a pedagogic function. It could contribute to make the different actors of the system more aware of their role in this larger structure, and of the requirements that follows from it. In this regard, the question is, so to say, not whether we should think of the criminal justice system as a system (at least at some level of abstraction this seems inevitable), but what kind of system we should consider it to be. It certainly matters whether the actors of the system gives priority to strategies of social management or to more principled accounts about the aim and function of the criminal law. ${ }^{11}$ More generally, it is of importance for the function of the system as a whole that the different actors within the system, such as the police, the defence or the prison services, are aware about how the more general principles of the system should guide their concrete tasks. In other words; also from a practical and functional point of view a normative theory of the criminal justice system is of importance. The pedagogic function is above all to be realized through academic teaching, by the education of future lawyers and other actors within the system.

3. The Prescriptive Function: A theory of a criminal justice system could, finally, play an important role in guiding the further interpretation and development of the criminal law. Particularly the contemporary transnational development requires discussion of the meaning of upholding a certain system structure of the criminal law. It is today often underlined that the national criminal justice system - as a more or less specific and autonomous system that represents certain important values - is challenged under the pressure of transnational legal development. ${ }^{12}$

Also with regard only to the national level, it is important to discuss the deeper meaning of having a criminal justice system. The national systems are in constant development due to societal, not least technological, changes. New normative or institutional elements are added; some old ones disappear or are removed. Technological inventions create for instance new opportunities for surveillance and evidence (cf., DNA), new forms of punishments (cf., foot-chains), new possibilities for communication within the system and between the system and society (cf., TV-trials) and also for new forms of crime (cf., Internet-crime). However, it is not 
obvious what kind of solutions that should be used in order to deal with these continuously new challenges (or possibilities). The conventional model has, after all, its limits when it comes to providing answers on such questions: The fact that it might be possible to trace a conventional model should not be confused with the adequacy of this model. The paradigmatic status and wide acceptance of this model could at best be seen as a symptom of such adequacy. To provide it with normative force it has, however, to be supplemented with deeper rational justification.

It is here important to add that the use of the term "criminal justice system" has a certain rhetoric force. In the Western discourse this term is loaded with ideas and values of the democratic Rechtsstaat, as indicators of authority and legitimacy. As such, the use of the term in other contexts, for instance in the mentioned transnational context, might create associations to such authority and legitimacy, despite potential deficiencies. If, for instance, the structure that is developed within EU criminal law is described as an "EU criminal justice system", this easily implies the presence of some kind of autonomous, complete and functioning whole. Hence, the use of this term will probably make it easier to gain support for the further development of EU criminal law than if it is, for instance, described as a multi level entity that struggles with the existence of competing Member State perspectives. Also, in order to resist that kind of legal or political rhetoric a deeper understanding - a theory - of the criminal justice system is needed. ${ }^{13}$

4. The Coherence Function: Through the above mentioned functions, a theory could also contribute to the upholding and improvement of the coherence of the (positive) criminal justice system as such. Today it becomes increasingly harder to understand legal problems in isolation to their specific area, such as for instance in police law. Contemporary developments as outlined above, and contemporary challenges with regard to the context of criminality, in many occasions asks for solutions or answers that are not necessarily prescribed by the specific regulations at stake. Also classical distinctions within the criminal justice system dissolve or become challenged, such as the distinction between police power and military power or between criminal and administrative penalties. To an increasing degree an understanding of contemporary problems must therefore be considered in relation to the system as a whole. In this regard, a theory that communicates how the different elements of the system are linked together, through more basic principles, seem important with regard to the coherence of the system.

Bearing these different functions in mind, it is now time to provide an account of the content of a theory of the criminal justice system. I shall in the rest of this 


\section{Linda Gröning}

article limit myself to provide the contours of different supplementing building blocks and methodological perspectives that seem needed in order to develop such theory.

\section{Building Theory}

\subsection{Methodological Starting Points}

This article approaches theory of the criminal justice system as a matter of normative reconstruction of its principled structure. The criminal justice system is primarily sought understood through the elaboration of a coherent framework of general principles that prescribes the system's needed content, i.e. its constituting elements. Basically, the principles determine the systems' content, by either prescribing certain elements, such as the presence of certain norms (such as norms that defines punishable offences, prescribes certain procedures or certain forms of punishment), functions or institutions (such as the function of investigation or the presence of a defence), or by governing the relations among such elements (such as the relation between substance and procedure).

The theory aimed at, in other words, provides an account of the principles that steers, or should steer, the criminal justice system as a whole. Methodologically it claims to represent a (internal) legal perspective by being anchored in basic constitutional principles and values. The theory also builds upon existing discussions about different aspects of the criminal law and its institutionalised setting and insists upon linking these aspects together in a coherent framework. In the end, however, a principled framework of the criminal justice system, as well as its constitutional foundation as such, must be understood as anchored in rational argumentation. In this regard, a theory of the criminal justice system is inevitably philosophically founded. At the same time such theory must abstract from, and must draw upon knowledge about, the content of existing systems and their social and cultural settings. As will be developed below, it is not possible to construct theory of the criminal justice system in isolation from such "reality".

A central element in a theory of the criminal justice system concerns the notion of a "system". In brief, this article carries the argument that the systematic character of the criminal justice system is in essence a matter of a certain unity, in terms of coherence, among its different elements. ${ }^{14}$ In this regard, an elaboration of the principled framework of the system is an attempt to further explain its systematic character.

At the empirical level, contemporary literature reflects some doubts as concerns the systematic character of existing criminal justice systems. Some authors have even suggested that the criminal justice system is a non-system - even 
though there is a widely spread agreement that current criminal justice systems at least to some degree work as systems when it comes to securing social control by means of norms and punishment. ${ }^{15}$ These discussions have, to a large extent, been focused on how different actors within the system are co-ordinated and interdependent in their practices, and not on the principles that steers (or should steer) the system and its components. ${ }^{16}$ This sociological dimension of the criminal justice system is a far-reaching subject that I will not explore further in this article. Notwithstanding the systematic character of existing criminal justice systems, my theory will start from the assumption that such a system should to a high degree function in accordance with a principled structure.

The conventional model of a criminal justice system seems to integrate certain aspirations of such a principled approach, although not explicated through a more complete theory. At least, this model refers to the idea that the system contains specific normative and institutional elements that have to interact in a specific way in order to put effect to the criminal law. Moreover, the conventional understanding refers precisely to a structure of more or less articulated basic ideas and principles regarding the deeper meaning of the criminal justice system, which in essential aspects are expressed in the ideas of the system's norms and institutional organisation. ${ }^{17}$ The aim of general prevention seems fundamental in this regard, as it is conventionally considered both to justify a criminal justice system as such and to at least to some extent guide its institutional and normative content - although it is unclear how this aim interplays with more specific functions at different institutional levels of the system. More generally, the basic ideas and principles embedded in the conventional model, mainly centred on justifying the institution of punishment (e.g., principles of responsibility), are to a large extent derived from the basic values of the democratic Rechtsstaat.

Furthermore, the claim of some kind of a principled structure is in legal theory presented as inherent in the idea of law, deriving from basic constitutional values. ${ }^{18}$ This is, not least, seen within the domain of criminal law doctrine where the criminal law is basically approached as a coherent body of rules, concepts and principles, deriving from basic constitutional requirements. Following this tradition I shall argue that any claim of penal power must correspond to certain basic system requirements. The principled character of the system is in the end understood as a criterion for its legitimacy. ${ }^{19}$

It is, however, part of the problem when developing a theory of the criminal justice system to answer to what degree it has to be a principled structure and what kind of principles it should be constructed from. What has the system to be like, in its constituting elements, in order to provide legitimate decisions about 


\section{Linda Gröning}

crime and punishment? It seems quite clear that the criminal justice system cannot adequately be understood only as a principled and normative structure. It must to a large extent be understood also as a social and cultural phenomenon. The elements of any legal system must, in this regard be seen as impregnated by the system's specific historical, economic, ideological or political settings. ${ }^{20}$ Therefore it is central when developing a theory of the criminal justice system to find out to what extent a criminal justice system is contingent on culture, and whether, or to what extent, there are values and principles that are universally prescriptive and therefore necessary elements of any criminal justice system.

I will now proceed towards an answer to this question, by providing some thoughts about the building blocks of a theory of a criminal justice system. Firstly, I will provide some notes on the fundamental structure of the criminal justice system as a structure that is claimed to be found in, or that could be abstracted from, any system that exercises penal power. From this starting point, I will then further elaborate on the needed content of a criminal justice system, in terms of general principles that any system should be structured from. Such general principles ultimately reach beyond the positive law and must be anchored in some dimension of morality, which could be seen as internal or external to the legal order. $^{21}$

\subsection{The Fundamental Structure of the Criminal Justice System}

On a methodological level, a fundamental structure is ultimately claimed to be empirically founded in all existing legal orders that exercises penal power. It should, however, be noted that even though a fundamental structure is empirically observable in all existing systems, it is not (only) motivated by empirical grounds. It is a structure that is almost conceptually implied by the idea of public administration of punishment.

A fundamental structure could, however, only be reconstructed at a very high level of abstraction and is therefore almost empty of information concerning the content of the system. The specific content of the system must to a significant extent be understood as a matter of cultural differentiation. ${ }^{22}$ Or more precise: The criminal justice system must in its totality be understood as a cultural phenomenon that functions and evolves in a given cultural context. Some structural aspects could, however, be understood as common to different legal cultures and in this sense "fundamental", while others could not. It seems clear that, when searching for concretisation, there is significant variation in the normative and institutional content of existing criminal justice systems. Different systems have at least to some extent various crime provisions, different institutional organisation, 
different rules of imputation, different ways of perceiving and regulating the interdependence between substance and procedure and so forth. ${ }^{23}$

The criminal justice system could in its fundamental structure initially be approached by means of three different components that represent different basic building blocks of the criminal justice system. These components are the system's essential meaning, its basic concepts and its basic functional elements. The latter could primarily be divided into normative functional elements (norms) and institutional functional elements. These different components are strictly speaking different perspectives on the criminal justice system and cannot be separated nicely from each other. It is, however, important to understand the specific role of each element in order to understand how the system's more concrete structure and content is formed. Furthermore, it should be noted that in a complete theory of the criminal justice system these components might be supplemented with other elements that are claimed to belong to a fundamental structure. My claim in this article is in this regard limited to the articulation of some central dimensions of a theory, taking into account that there might also be others to add. Having clarified this, I will now further explain the different fundamental elements of the criminal justice system.

The essential meaning could be described as the constitutional meta-principle of the system. The principled framework of the system is ultimately understood to be organised around and anchored in such meaning. This viewpoint should not be confused with the argument that the criminal justice system could be understood in terms of one distinct purpose alone. At a more concrete level, the criminal justice system typically embodies a multitude of different aims and values. The overall aim for the police might, for instance, be formulated in terms of maintenance of safety, security and order in society and a more concrete purpose of the investigation might be to clarify if the conditions for imposing criminal liability exist. ${ }^{24} \mathrm{~A}$ central argument of this article is, however, that without adhering to some kind of deeper meaning it is impossible to conceptualise the criminal justice system as a coherent whole.

Furthermore; one thing is that any criminal justice system must be understood through an essential meaning. Another thing is what the essential meaning is understood to be. Any criminal justice system could, probably, be understood by reference to the punishment of crimes. If one asks for a more substantive understanding of the essential meaning, existing and historical systems provide for a multitude of suggestions, such as societal utility, retribution or effectuation of sovereign will. Therefore, when it comes to adding substance to the meaning of a criminal justice system, it seems as it is no longer similarly adequate to speak of a 


\section{Linda Gröning}

fundamental structure. I shall, however, argue in the following that in terms of a principled structure a criminal justice system is essentially about the protection of individual autonomy.

The basic concepts could be understood - as in the words of George P. Fletcher - as the conceptual grammar of the criminal justice system. The most basic concepts of the criminal justice system are the concepts of crime - the violation of a norm designed to secure certain interests - and punishment as the response to a crime. It seems impossible to speak of a criminal justice system, or to explain its different elements, without adhering to these concepts. ${ }^{25}$ Also any opinion on the needed content of the system, at least to a significant degree, will rest upon the understanding of crime and punishment (and their relation), an understanding which in turn depends on the essential meaning. The conventional model rests, in this regard, upon the understanding of punishment as conceptually tied to crime as wrongdoing, an understanding that, for instance, links to certain principles for criminal liability. ${ }^{26}$ Regarding the more specific understanding of the concepts of crime and punishment, and their interrelation, existing criminal justice systems reveals a multiplicity of different perspectives. For instance the systematisation of the prerequisites of punishability differs also between systems with similar legal traditions. ${ }^{27}$ Except for the concepts of crime and punishment there are other concepts that have this kind of status as conceptual premises of the system. The concepts of guilt, responsibility and (criminal) justice are obvious candidates.

The basic functional elements are centred on a basic principle that prescribes that the system should be functional in regard to implementing the meaning of the system. The essential meaning and the basic functional principle could thus be described as intertwined in a requirement that a criminal justice system functions in a way that reflects its meaning. There are certain elements that seem required in any system that exercises penal power. These elements could be viewed as necessary parts of any functioning criminal justice system, as needed functional elements, and could as such be described as its spine or skeleton. I suggest the following elements as basic functional elements.

\section{The function of norm creation-Identification of crimes (and their punishment) at the norm level}

Firstly, there is the elementary function of norm-creation, in the meaning the act of identification of certain behaviour or actions as crimes, and of certain kinds of punishment. This function is conventionally associated with criminalisation and the institution of the lawmaker. ${ }^{28}$ But norm creation could also take place at other 
"levels" or institutions of a criminal justice system, such as within a court. ${ }^{29}$ Furthermore, it should be noted that the function of norm-creation requires an actor performing it, which in turn presupposes some kind of competence-giving norms. According to the conventional understanding, the criminal justice system is subordinated to certain constitutional procedures and/or norms for the process of law-making. The function of norm creation, in the end, also refers to ideas of crime and punishment and related concepts, since the understanding of these concepts steers the identification of relevant norms.

\section{The body of norms}

Secondly, any criminal justice system must contain codified or non-codified general norms about crime and their punishment, most typically as a result of an act of norm-creation. It also seems reasonable to add norms about procedures to this category. The point is, however, that if it at all should be adequate to speak of a system, there has to be some kind of general norms defining the punishable offences. Without such norms all that remains is an aggregation of different kinds of violent actions undertaken by those in control. The body of norms might also refer to norms of a higher constitutional character that are not unique for the criminal justice system but that are valid in this system as a part of a more general constitutional order. In this regard, the conventional model perceives the criminal justice system as a sub-system to the legal order of the (nation) state, and as such subject to certain constitutional principles.

\section{The functions of the application and implementation of norms}

a) Investigation of crime

b) Judgment on criminal responsibility and punitive response (cf. adjudication of punishment)

c) Administration (execution) of punishment

Finally, any criminal justice system is centred on functions or procedures for the application and implementation of general norms in concrete cases. More specific, any system embodies the function to protect the interests behind the norms by means of realising the threat of punishment when crime is actually committed. This function of application and implementation of norms typically embodies, above all, three sub-functions: The functions and procedures of a preliminary identification of crime, i.e. investigation into possibly committed crimes, of judging on whether a crime has been committed, including questions relating to re- 


\section{Linda Gröning}

sponsibility and punitive responses, and of administrating or executing the concrete punishment.

All these different elements of a fundamental structure are, in terms of a theory of the criminal justice system, to be understood as necessary but not sufficient elements. In order to elaborate further on the principled structure of the system, these basic elements must be concretised with regard to more specific normative departing points, and also with regard to the more specific working premises of the system. In order to proceed towards a thicker theory it is, in other words, needed to add substance. In doing so, I will in the following further discuss the principled framework of the criminal justice system, by further clarifying its essential meaning and its cultural elements.

\subsection{Adding Substance: The Principled Framework}

\subsubsection{Autonomy Protection as the Essential Meaning}

The essential meaning of a criminal justice system is to be found in the value to protect individual autonomy (cf., human dignity and equality) that more generally underlies the democratic Rechtsstaat. This value is the foundation of international declarations on human rights (eg., ECHR, ECFR UN Declaration of Human Rights), as well as of every Western constitution, and could as such be seen as a primary constitutional principle. The value of individual autonomy is also the departing point and ethical foundation of Western criminal law. The criminal law is constructed from the idea of the individual as a being with capacity for autonomy and responsibility. It should, however, be clear that the perspective adumbrated in this article is based upon a substantive conception of law, and on a substantive perspective of legitimacy, according to which the binding force of law ultimately lies in its (moral) legitimacy. In the end, the adequacy of adhering to the value of autonomy protection as the essential meaning of the criminal justice system can not be defended on empirical grounds, such as by showing its status in positive law. Its adequacy must ultimately be defended in terms of rational moral argumentation as the foundation of the entire legal project. ${ }^{30}$

\subsubsection{Understanding Function through Meaning: Deriving Specific Principles}

The basic substance of the criminal justice system could, at a high level of abstraction, be understood through the value to protect individual autonomy as a set of basic (constitutional) principles. All specific principles that steer the content of the system, and its different elements, are to be understood as anchored in, and interrelated through, these basic principles. This means, for instance, that specific principles that steers the administration of punishment (such as principles con- 
cerning the reintegration of prison inmates) and criminalisation principles (such as principles of proportionality) must be possible to explain as interrelated at a higher constitutional level.

There are basically two kinds of principles that could be derived from the value of autonomy protection; positive principles that aim at crime prevention (or crime control) and negative or limiting principles that aim at prevention of abuse of power. ${ }^{31}$ The positive principles prescribe what is needed in order for the system to secure the horizontal aspect of autonomy protection between individuals in society. The negative principles limit the extension and content of the system and thus primarily refer to the vertical relation between individual and political power. The relation between these two categories is generally so that positive principles motivate the existence of different normative or institutional elements as such in the criminal justice system, while the negative principles enter in regard to each of these elements, as limiting requirements as regards form and content.

Through these basic principles of autonomy protection the needed functional elements and principles of the system could be further elaborated. The overall question at stake is how the basic principles could be differentiated into more specific principles about the required normative and institutional elements of the system, and their interrelations. In order to reach a theory, such principles must be elaborated at each level of basic functional elements, i.e., with regard to the function of norm-creation, the body of norms and the functions of the applications and implementation of these norms. Such an exercise requires answers on a multitude of different principled questions, at each functional level. What kinds of institutions or procedures are, for instance needed with regard to the creation of penal norms, and according to what principles, if any, should this function be structured $?^{32}$ Or: what principles should steer the administration of punishment, such as imprisonment? ? $^{33}$

It seems quite clear that the aspects of crime prevention and prevention of abuse of power have different impacts and concrete manifestations on different functional levels of the system. They may for instance be transformed into different kinds of principles of evidence at a judicial level or into a more general requirement of high rate of crime disclosure. It seems also reasonable that the system does not in each specific function account for a "perfect balance" between different needed basic principles, as long as the system as a whole secures such balance. But a core question is then: according to what principles should the different functional elements interplay in order to secure a defensible whole?

In providing an answer to this question, a theory of the criminal justice system must elaborate a set of principles with regard to the criminal justice system as a 
functioning whole. In this regard, a theory of the criminal justice system links to the different discussions in and about the criminal law that has been centred on deriving principles from the Rechtsstaat foundation. The discussion on general principles of the criminal law is central in this regard, as it offers insights on principles of criminalisation, responsibility, and sentencing. ${ }^{34}$ In addition there are valuable contributions concerning the principled framework of the criminal process. ${ }^{35}$ The discussion on basic constitutional principles, and particularly on human rights, is also of significance. ${ }^{36}$ A theory of the criminal justice system links together these existing discussions in a coherent principled framework.

In elaborating such a framework, a theory of the criminal justice system must generally take into account different kinds of empirical knowledge when the arguments at issue presuppose or refer to such knowledge. Sociological knowledge is for instance central to the understanding of the nature of the societal problems that the criminal law refers to; how are for instance contemporary phenomena such as terrorism, organised crime or trafficking really to be understood? And the idea of individual responsibility as a premise for crime at least to some extent requires knowledge concerning our capacity to act as responsible beings, a discussion that relates to for instance neuroscience and psychology. ${ }^{37}$ In this regard empirical knowledge ultimately operates like a test for validity of the theoretical model at stake. This remark links us to a more basic insight about the empirical dimension of the criminal justice system - an insight with impact on the content of a theory about it.

\subsubsection{Empirical Elements: The Criminal Justice system between Facts and Norms}

A criminal justice system cannot be understood at the normative level alone, but must be understood as a phenomenon in the intersection between facts and norms. At the same time as such system is always built upon certain basic (normative) principles, it is inevitably characterised as being an instrument for implementing principles into a given social reality. A criminal justice system functions (and should function), in other words, also as a social system. In its empirical dimension, the criminal justice system is built upon certain working premises that is not universal, but to a significant degree dependent on culture, society and tradition. Such empirical premises are, for instance, the existence of certain social problems (cf. crime rates), prevailing political and legal ideologies, available economic recourses and established institutional structures and practices. In this regard, also our most basic intuitions about crime and punishment, at least to certain extent, seem related to social mechanisms. ${ }^{38}$ The differences between exist- 
ing systems, in the systematisation of the prerequisites of punishability are here noteworthy.

This insight has implications for the possibilities as such to conceive a "thicker" or more substantive theory of the criminal justice system. At least it seems not possible to elaborate upon a more comprehensive principled structure without integrating a component of cultural openness, taking into account also the systems' success in being functional in a given social setting. A principled structure must, in other words, be constructed from both (more) deontological and culturally contingent elements.

The only way to proceed towards a more substantive theory is therefore to further elaborate basic principles and fundamental functional elements in light of knowledge about the working premises of existing criminal justice systems. The elaboration of more concrete principles requires at several points a deeper understanding of the interplay between norms and culture in the criminal justice system, as well as of more concrete manifestations of such interplay. In this regard, a central question is how our intuitions of crime and punishment are affected by social or cultural mechanisms. The concepts of crime and punishment are also more generally central to a theory, as these concepts offers methodological key perspectives for the understanding of the criminal justice system. These concepts have references to many different discourses on criminal law, and also links to different cultural traditions, and limitations, regarding how to punish and what to define as crime. General principles concerning, for instance, forms of punishment must in this regard be elaborated through a deeper understanding of these discourses, and their interplay.

The principled framework of the criminal justice system must, more generally, in several aspects be developed by means of evaluation of the continuous development of the criminal justice system as a societal institution. Apart from the contributions offered by other empirical research fields, contributions from comparative criminal law seem here to be of particular importance. Comparative research provides examples of how basic principles could be transformed into specific functional solutions in a criminal justice system, such as, for instance, the basic principle of effective crime control might support the use of DNA surveillance. At some level of concretization, it is reasonable to believe that different solutions have less principled relevance. ${ }^{39}$ In other words, at some level of concretization, several solutions seem possible within the principled framework of a "criminal justice system". It is here worth noting that the conventional model refers to a paradigmatic understanding that is shared by the existing Western (na- 


\section{Linda Gröning}

tional) criminal justice systems, systems that in many aspects differ in their more concrete normative and/or institutional solutions.

In the end, the cultural contingency of the criminal justice system raises some doubts about the possibilities of a more substantive theory. Does not such a theory after all have to be a theory about a specific system or system context? At least it seems like a true challenge to develop principles for the content of a criminal justice system that could be universally understood and adopted. This challenge has obvious references to the transnational legal development, a development that is at the apex of contemporary changes within criminal law. Therefore it is, as a final remark, interesting to note that this development in fact challenge the paradigm of the national criminal justice system. It is, however, in no ways obvious whether this implies a (theory of a) criminal justice system that transcends national boundaries, or if it rather implies that the development of transnational criminal law has been taken a step to far.

\section{Concluding remarks}

This article has provided some initial thoughts about a theory of the criminal justice system, thoughts that could - and should - of course be discussed further. The construction of a more substantive theory of the criminal justice system must after all be seen as a project that asks for wide-ranging research collaboration. This project must include research within criminal law and its different disciplines, legal theory more generally and, to a significant degree, also contributions from many other fields of knowledge. Given this magnitude of the project, one might be tempted to simply leave it behind, particularly when taking into account the fact that we are perhaps striving to achieve the impossible. However, given the important functions that a theory of the criminal justice system fulfils, this is not a preferable alternative. And perhaps the magnitude of the project only makes it more fascinating after all.

\section{Notes}

1. Linda Gröning, Juris Dr. (Lund 2008), numera anställd som førsteamanuensis vid det juridiske fakultet, universitetet i Bergen (assistant professor på engelska tror jag) med ett post doc engagemang inom forskningsprojektet "strafferettssystemets funksjonalitet".

2. The arguments of this article are further elaborated in Rethinking the Criminal Justice System: towards a System Model for Transnational Criminal Law (book manuscript 2011).

3. The state is conventionally viewed as the (exclusive) basis for a criminal justice system. Today, competence to exercise penal power is, however, to a certain extent established at the transnational level (cf., EU criminal law and international criminal law), although a more complete autonomous transnational criminal justice system do not (yet) exist. On this 
matter regarding EU criminal law, see further L. Gröning, 2008, EU, staten och rätten att straffa: Problem och Principer för EU:s straffrättsliga lagstiftning, Stockholm: Santérus, pp. 5-58, 247-265.

4. Theories and models for empirical studies of existing criminal justice systems have been developed within the fields of sociology and criminology. For different perspectives in this regard, see Managing Criminal Justice: A collection of Papers, D. Moxon, ed., 2004, London: Home Office Research and Planning Unit. There also exists a multitude of different more descriptive and often also critical accounts of different national criminal justice system. See, inter alia, M. Cavadino \& J. Dignan, 2007, The Penal System: an Introduction, $4^{\text {th }}$ ed., London: Sage Publishing.

5. The context of transnational criminal law is of particular interest with regard to the reconfiguration of the criminal justice system, see further L. Gröning, 2010, "A Criminal Justice System or a System Deficit: Notes on the System Structure of the EU Criminal Law", 18 European Journal of Crime, Criminal Law and Criminal Justice, pp. 115-137.

6. I have explicated the conventional model, and its particular system understanding, more in detail in other works and will therefore not go further into the content of this model in this article. See further inter alia, Gröning (2008) pp. 86-95 and L. Gröning, "Security, Justice and the Criminal Justice System: Remarks on EU Criminal Law", New Landscapes of Justice and Security, B. Hudson \& S. Ugelvik, eds., forthcoming Routledge (February 2012).

7. Cf., A. Ashworth \& M. Redmayne, 2010, The Criminal Process, $4^{\text {th }}$ ed., Oxford: Oxford University Press, p. 2.

8. For a discussion on this matter, see inter alia, A.J. Szwarc, 2006, "Eurodefence - Support for the Defence" in B. Schünemann, ed., Ein Gesamtkonzept für die europäische Strafrechtspflege/A Programme for European Criminal Justice, Köln: Carl Heymanns Verlag, pp. 429-439.

9. The model put forward by Nils Jareborg, concerning the aim(s) of punishment is, however, an important exception. This model articulates the basic institutional levels of the penal system and clarifies, from this starting point, how the system integrates different answers on the question(s) about the aim of punishment. See, inter alia, N. Jareborg, 1988, "The Coherence of the Penal System" in Essays in Criminal Law, N. Jareborg, ed., Uppsala: Iustus, pp. 105-121.

10. It is here interesting to note that the criminal justice system, above all, has been studied from sociological and empirical perspectives.

11. Ideas of social management, or "managerialism", are based upon the (pragmatic) notion that modern managerial techniques can be successfully applied to the problems of crime and punishment. See further, Cavadino \& Dignan (2007) s. 29.

12. See, inter alia, P.O. Träskman, 2002, "Strafflagen för Europeiska Unionen - Fakta och Fiktion”, 87 Svensk Juristtidning, pp. 359-362.

13. On this matter, see further Gröning (2010).

14. Unity is in this regard seen as a minimum requirement for any system. Cf., M. Van de Kerchove \& F. Ost, 1994, Legal System between Order and Disorder, Oxford: Oxford University Press, pp. 5-6.

15. Cf., "It is not a system in the sense of coordinated decision making bodies[...] many working groups within criminal justice are relatively autonomous and enjoy considerable dis- 
cretion - even though there is a practical interdependence of the various agencies.", Ashworth \& Redmayne (2010) p. 17, see also Cavadino \& J. Dignan (2007) p. 8.

16. For an interesting study in this regard, see Coordinating the Administration of Criminal Justice: the Interdependence Project in Avon and Somerset, Report (12/01/1986) to the Home Office, Walter P. Loughlin, Vera Institute of Justice.

17. This understanding of an interaction between the deep-structural viewpoints and the normative and institutional structure of the criminal justice system has clear links to the theory by Kaarlo Tuori of the different layers of law. See further K. Tuori, 2002, Critical Legal Positivism, Aldershot: Ashgate, particularly part III.

18. See inter alia, Van de Kerchove \& Ost (1994), Legal System between Order and Disorder, Oxford: Oxford University Press, pp. 7-9.

19. Cf., "[...] the legitimacy of a justice that is not national but is nonetheless criminal, that is, coupled with heavy sanctions including life imprisonment, calls for a common grammar to provide a consistency sufficient to protect both victims and accused from arbitrariness." M. Delmas-Marty, 2009, Ordering Pluralism: a Conceptual Framework for Understanding the Transantional Legal World, Oxford: Hart Publishing, p. 75.

20. Cf., R. Cotterrell, 2008, "Comparative Law and Legal Culture" in Reimann/Zimmermann, eds., The Oxford Handbook of Comparative Law, Oxford: Oxford University Press, p. 709.

21. Cf., R. Dworkin, 1967, "The Model of Rules", 35 The University of Chicago Law Review, pp. 23.

22. For an account of the social and cognitive mechanisms by which individuals evaluate crime and punishment, see D. Braman, D.M. Kahan \& D.A. Hoffman, 2010, "Some Realism about Punishment Naturalism", 77 The University of Chicago Law Review, pp. 15311609.

23. Cf., inter alia, A. Eser, 1997, "The Importance of Comparative Legal Research for the Development of Criminal Sciences", in Law in Motion, R. Blanpain, ed., The Hague: Kluwer, p. 514-515.

24. For an informative overview of the different particular aims and principles that steer the different actors within the Danish criminal justice system, see V. Greve, 2011, "The Criminal Justice System in Denmark" in Studien zum dänishen Strafrecht/Studies in Danish Criminal Law, V. Greve \& K. Cornils, eds., Copenhagen: DJØF Publishing, pp. 15-67.

25. Criminal law theory reflects some controversies concerning whether the concept of crime or the concept of punishment is primary in a reconstruction of the criminal law, and to some extent these concepts offer different methodological perspectives in this regard. Cf., G.P. Fletcher, 2007, The Grammar of the Criminal Law, Vol. One, New York: Oxford University Press, pp. 222-223.

26. See further for one account including both reflections on the nature of punishment and principles of criminal responsibility, H.L.A. Hart, 1968, Punishment and Responsibility Essays in the Philosophy of Law, Oxford: Oxford University Press.

27. Cf., Eser (1997) p. 514.

28. The conventional model reflects some controversies as concerns the inclusion of the legislator, and the process of legislation, in the criminal justice system and this matter touches upon the controversial issue of the division between law and politics. Taking into account the contemporary increasing interest for theories on criminalisation and the strong position 
of the principle of legality within criminal law it seems, however, most adequate to include also the legislative level in the conventional model. Another issue is that the criminal justice system is to a large centred on the function(s) to give effect to the norms of the criminal law.

29. Cf., Jareborg (1988) p. 107.

30. For a further elaboration of this perspective and its impact in constitutional and criminal law, see Gröning (2008) pp. 145-175.

31. For a perspective on these different dimensions of autonomy protection, see J. Jacobsen, 2009, Fragment til forståing av den rettsstatlege strafferetten, Bergen: Fagbokforlaget, pp. 522-611.

32. In this regard, there is an increasing focus on the law-maker in legal theory, and on principles that should steer legislation. For an account that articulates such principles from a more basic constitutional perspective deriving from individual autonomy, see L. Wintgens, 2006, "Legisprudence as a New Theory of Legislation" 19 Ratio Juris, pp. 1-25.

33. For a discussion on this matter, see L. Gröning, 2011, "Principer för straffverkställigheten: Frågan om fängelsestraffets innehåll", manuscript $29 \mathrm{pp}$, forthcoming.

34. See, inter alia, Douglas Husak, 2007, Overcriminalisation - The Limits of Criminal Law, Oxford: Oxford University Press, Victor Tadros, 2005, Criminal Responsibility, Oxford: Oxford University Press, and Andrew von Hirsch, 2001, Proportionalitet och straffbestämning, Uppsala: Iustus.

35. See, inter alia, Ashworth \& Redmayne (2010).

36. See, inter alia, A Ashworth and B. Emmerson, 2001, Human Rights and Criminal Justice, London: Sweet and Maxwell, A Ashworth, 2002, Human Rights, Serious Crime and Criminal Procedure, London: Sweet \& Maxwell.

37. For an account on this matter that challenges the idea that human beings have capacity to make free and conscious decisions, and hence also responsibility as a fundament in the criminal law, see A.R. Cashmore, 2010, "The Lucretian swerve: The Biological Basis of Human Behaviour and the Criminal Justice System", 107 Proceedings of the National Academy of Sciences of the United States of America, pp. 4499-4504.

38. See further, Braman, Kahan \& Hoffman (2010) pp. 1531-1609.

39. Mirjan R. Damaška offers with regard to the criminal process valuable comparative insights on the room for cultural differentiation. See M.R. Damaška, 1986, The Faces of Justice and State Authority, London: Yale University Press. 